\title{
The effectiveness of self-regulation in limiting the advertising of unhealthy foods and beverages on children's preferred websites in Canada
}

\author{
Monique Potvin Kent* and Elise Pauzé \\ School of Epidemiology and Public Health, Faculty of Medicine, University of Ottawa, 600 Peter Morand Crescent, \\ Room 301J, Ottawa, Ontario, Canada, KIG $5 Z 3$
}

Submitted 23 May 2017: Final revision received 22 November 2017: Accepted 12 December 2017: First published online 13 February 2018

\begin{abstract}
Objective: To assess the effectiveness of the self-regulatory Canadian Children's Food and Beverage Advertising Initiative (CAI) in limiting advertising of unhealthy foods and beverages on children's preferred websites in Canada.

Design/Setting/Subjects: Syndicated Internet advertising exposure data were used to identify the ten most popular websites for children (aged 2-11 years) and determine the frequency of food/beverage banner and pop-up ads on these websites from June 2015 to May 2016. Nutrition information for advertised products was collected and their nutrient content per $100 \mathrm{~g}$ was calculated. Nutritional quality of all food/beverage ads was assessed using the Pan American Health Organization (PAHO) and UK Nutrient Profile Models (NPM). Nutritional quality of CAI and non-CAI company ads was compared using $\chi^{2}$ analyses and independent $t$ tests.

Results: About 54 million food/beverage ads were viewed on children's preferred websites from June 2015 to May 2016. Most (93.4\%) product ads were categorized as excessive in fat, $\mathrm{Na}$ or free sugars as per the PAHO NPM and $73.8 \%$ were deemed less healthy according to the UK NPM. CAI-company ads were $2 \cdot 2$ times more likely (OR; $99 \% \mathrm{CI})$ to be excessive in at least one nutrient $(2 \cdot 2 ; 2 \cdot 1$, $2 \cdot 2, P<0.001)$ and 2.5 times more likely to be deemed less healthy $(2 \cdot 5 ; 2 \cdot 5,2 \cdot 5$, $P<0.001)$ than non-CAI ads. On average, CAI-company product ads also contained (mean difference; 99\% CI) more energy (141; 141.1, $141.4 \mathrm{kcal}$, $P<0 \cdot 001, r=0.55)$, sugar $(18 \cdot 2 ; 18 \cdot 2,18.2 \mathrm{~g}, P<0 \cdot 001, r=0 \cdot 68)$ and $\mathrm{Na}(70 \cdot 0 ; 69 \cdot 7$, $70 \cdot 0 \mathrm{mg}, P<0.001, r=0.23)$ per $100 \mathrm{~g}$ serving than non-CAI ads.

Conclusions: The CAI is not limiting unhealthy food and beverage advertising on children's preferred websites in Canada. Mandatory regulations are needed.
\end{abstract}

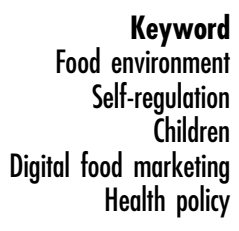

Approximately $12 \%$ of children globally have excess weight or obesity, putting them at increased risk of developing nutrition-related chronic diseases in adulthood $^{(1)}$. In Canada, obesity among children has tripled since the $1980 \mathrm{~s}^{(2)}$. Food and beverage marketing (hereafter referred to as 'food marketing' only) has been identified as a significant contributor to childhood obesity ${ }^{(3-6)}$. As such, the WHO has recommended that countries develop policies limiting children's exposure to food marketing that is high in fat, sugar and $\mathrm{Na}^{(7)}$.

Marketing to children in Canada is mostly self-regulated by industry. In 2007, sixteen food and beverage manufacturers established the Canadian Children's Food and Beverage Advertising Initiative (CAI); currently, seventeen large food and beverage companies and one fast-food restaurant chain participate. Under this initiative, eleven companies pledged to abstain from advertising to children under 12 years old while the remainder pledged to advertise only products considered 'healthier dietary choices' in schools, print media, television, the Internet and other media ${ }^{(8,9)}$. Each company defined what constituted advertising to children and set child audience thresholds that range from 25 to $35 \%$ (i.e. the percentage of the audience that must consist of children under 12 years old before the pledges apply) ${ }^{(9)}$. In December 2015, the CAI implemented uniform nutrition criteria for eight food categories ${ }^{(9)}$.

To date, most research in Canada has examined food marketing to children on television. On average, Canadian children (outside Quebec) view between four and seven food ads per hour per station ${ }^{(10,11)}$, and the majority of products advertised are unhealthy and high in sugar, fat 
and $\mathrm{Na}^{(12)}$. Evaluations of the CAI have shown that children's exposure to food and beverage advertising on television increased after its implementation and the healthfulness of foods advertised did not improve ${ }^{(13,14)}$. This outcome was partly attributed to the voluntary nature of the CAI and its lax nutrition criteria ${ }^{(13,14)}$.

Although television remains the dominant medium by which food companies target children in terms of spending $^{(15)}$, the food industry has increased its spending on digital marketing and children are being increasingly targeted online ${ }^{(15,16)}$. On the Internet, food companies can create 'branded environments' for their products that incorporate interactive components such as advergames (video games with embedded advertising), membership opportunities, contests and videos that solicit the attention of children ${ }^{(17)}$. They also place banner advertisements on third-party websites that appeal to children ${ }^{(18,19)}$.

The potential for marketers to reach Canadian children online is great given that $99 \%$ of children have access to the Internet outside school ${ }^{(20)}$. According to recent research, $30 \%$ of children in grades 6-12 are spending more than $2 \mathrm{~h}$ of their daily leisure time playing games or surfing the Internet on computers ${ }^{(21)}$. Little research in Canada has examined food marketing online, although some research has indicated that advergames, viral marketing and contests are frequently featured on child-directed websites hosted by Canadian companies participating in the $\mathrm{CAI}^{(22)}$. Other research has shown that almost $30 \%$ of foods advertised to children during their preferred television viewing have websites with childdirected content and a plethora of marketing techniques to keep children engaged on these sites ${ }^{(23)}$

No research has examined the effectiveness of the CAI in protecting Canadian children from unhealthy food advertising in digital media including display advertising (i.e. non-video banner and pop-up ads) on children's preferred websites in Canada. To fill this gap, the objectives of the current study were to examine the frequency and healthfulness of food advertising on children's preferred websites and to compare the frequency and nutritional quality of these food ads between companies participating in the CAI and those not participating (i.e. non-CAI companies). It was hypothesized that the CAI is not sufficiently protecting children online, that children are exposed to a large number of food ads on their preferred websites and that the healthfulness of advertised products is poor.

\section{Methods}

\section{Identifying children's preferred websites}

Syndicated Internet advertising exposure data for June 2015 through May 2016 were licensed from comScore. This company maintains a large Internet audience measurement panel and captures the online behaviour of
Table 1 List of top ten websites preferred by Canadian children aged $2-11$ years

\begin{tabular}{llrcc}
\hline Website & $\begin{array}{c}\text { Number of unique } \\
\text { child visitors per } \\
\text { month }\end{array}$ & $\begin{array}{c}\text { Reach } \\
(\%)\end{array}$ & $\begin{array}{c}\text { Composition } \\
\text { of unique } \\
\text { visitorst (\%) }\end{array}$ \\
\hline 1 roblox.com & 1369000 & $49 \cdot 6$ & $48 \cdot 8$ \\
2 coolmath-games.com & 312000 & 11.3 & $48 \cdot 4$ \\
3 animaljam.com & 303000 & 11.0 & $46 \cdot 7$ \\
4 kizi.com & 247000 & $9 \cdot 0$ & $30 \cdot 1$ \\
5 minecraft.net & 146000 & $5 \cdot 3$ & $27 \cdot 3$ \\
6 y8.com & 135000 & $4 \cdot 9$ & $22 \cdot 5$ \\
7 moviestarplanet.ca & 130000 & $4 \cdot 7$ & $36 \cdot 5$ \\
8 clubpenguin.com & 99000 & $3 \cdot 6$ & $36 \cdot 8$ \\
9 pbskids.org & 97000 & 3.5 & $40 \cdot 2$ \\
10 totaljerkface.com & 96000 & $3 \cdot 5$ & $31 \cdot 6$ \\
\hline
\end{tabular}

†Percentage of unique website visitors who are children aged 2-11 years.

40000 Canadians, including the websites they visit, their engagement with web content and their exposure to display advertising. The data on panellists' online activity are weighted and extrapolated to estimate the online behaviour of the entire Canadian population, which can be segmented by age, gender, household income and geographic location, among other characteristics. The most popular ten websites with advertising for March-May 2016 were determined using comScore's Media Metrix Key Measures Report for children aged 2-11 years from Canada (excluding Quebec). The most popular sites were those that had a minimum of 50000 unique child visitors and those whose composition of child visitors (i.e. the percentage of visitors who are children) reached a minimum of $15 \%$. This audience threshold was selected because it is the one applied by the Consumer Protection Act in Quebec, which prohibits all commercial advertising to children under 13 years of age in that province ${ }^{(24)}$. A total of thirty-seven websites for children aged 2-11 years met these criteria and the ten with the highest number of unique child visitors that contained advertising were selected for the current study (Table 1).

\section{Frequency of display advertising}

comScore's Ad Metrix Advertiser Report was used to identify the frequency of food display advertising (i.e. pop-up ads and non-video banner ads) viewed on each website from June 2015 to May 2016. This report provides the number of display ads viewed at the company and product level if these ads were viewed by at least fifteen panel members per month. It should be noted, however, that comScore's Ad Metrix module captures all display ads that were seen by Canadian panellists, including advertisements originating from food and beverage companies located outside Canada. Six Ad Metrix Reports per website were generated which encompassed six food and beverage advertiser categories as classified by comscore including: food and grocery, frozen food, alcoholic beverages, restaurants, dairy and beverages. Ad creative reports were generated for each advertiser on every 
website and the number of ads viewed in Canada on these websites and their content (i.e. name of products or brand logos advertised) were documented. Ads that did not feature food products or brand logos, including those that strictly advertised kitchen appliances, stores or nutritional supplements, were not included in the study.

\section{Classifying display ads}

Each ad was classified by food category, ad type (product or brand), food company and whether it belonged to a company participating in the CAI (CAI/non-CAI) as defined in Canada. A very similar voluntary initiative exists in the USA; however, some participating companies, commitments and products approved for advertising vary $^{(25,26)}$. Ads were considered brand ads if they did not feature a specific product. Ad impressions that were reported by comscore as food ads but whose content could not be seen in ad creative reports due to technical glitches were included in the study and categorized as unspecified (neither brand or product). Ads were coded into fifteen food categories: restaurants (fast food and dine-in); cakes, cookies and ice cream; cold cereal; snacks; sugar-sweetened beverages; tea or coffee; candy and chocolate; cheese; bread and pasta; $100 \%$ juice; yoghurt (including yoghurt beverages); water; alcohol; mixed category (i.e. featuring products from multiple food categories); and other. Products grouped in the other category were those that appeared infrequently, including frozen pizza, oil, condiments, other grain products, milk and butter, frozen vegetables, dried fruit and baby food.

\section{Nutritional analysis}

A nutritional analysis of all advertised foods was completed using the Pan American Health Organization Nutrient Profile Model (PAHO NPM) ${ }^{(27)}$ and the UK Nutrient Profile Model (UK NPM) ${ }^{(28)}$. The former was selected as it considers only negative nutrients (i.e. nutrients of public health concern such as sugar and $\mathrm{Na}$ whose consumption in excess is linked with adverse health outcomes), while the latter was selected because it has been validated $^{(29,30)}$ and considers both positive (i.e. components such as fruit and vegetable content that are compatible with a healthy diet) and negative nutritional components.

Nutritional information was collected for each advertised product and was drawn, in order of priority, from the Canadian company website, the Nutrition Facts table found in store, the US company website or the Canadian Nutrient File. Information collected included energy (kcal), total fat (g), saturated fat (g), trans-fat (g), Na (mg), carbohydrates $(\mathrm{g})$, fibre $(\mathrm{g})$, sugar $(\mathrm{g})$ and protein $(\mathrm{g})$ per stated serving. This information was standardized and expressed based on servings of $100 \mathrm{~g}$ for both foods and beverages. The specific density $(\mathrm{g} / \mathrm{ml})$ of beverages was used to convert millilitres into grams ${ }^{(31)}$. Average nutrient content per $100 \mathrm{~g}$ was calculated for ads featuring multiple products. Beverages were excluded from these calculations if the ad featured both foods and beverages because the UK NPM (described below) classifies them according to different cut-off scores.

Both researchers coded each product and brand ad as unprocessed, processed or ultra-processed according to PAHO definitions ${ }^{(27)}$. Brand ads were categorized as ultraprocessed if all products within their portfolio met this criterion, whereas those that encompassed products of various levels of processing were not coded at all. All fastfood restaurant product or brand ads were categorized as ultra-processed unless they featured a processed or unprocessed product exclusively. The inter-rater reliability for this classification was $88.3 \%$ and was calculated as follows: $1-(51$ disagreements/437). Discrepancies were discussed and consensus on the final categorization was reached. However, due to this discrepancy, the PAHO NPM was applied to all advertised foods rather than solely to processed or ultra-processed products as suggested in the PAHO NPM guidelines ${ }^{(27)}$. Ads were classified according to whether they were excessive in fat ( $\geq 30 \%$ of total energy), saturated fat ( $\geq 10 \%$ of total energy), transfat ( $\geq 1 \%$ of total energy), $\mathrm{Na}(\geq 1 \mathrm{mg}$ per $1 \mathrm{kcal})$ and free sugars ( $\geq 10 \%$ of total energy) as per the PAHO NPM ${ }^{(27)}$. They were also classified as excessive or not in at least one of these nutrients. The products' content of free sugars was estimated using formulas suggested by the PAHO ${ }^{(27)}$.

Product ads were also classified using the UK NPM. Based on $100 \mathrm{~g}$ servings, each product was scored according to its content of energy, saturated fat, total sugar, Na, fruit/vegetables/nuts, fibre and protein, and its overall score was calculated as per the methodology ${ }^{(28)}$. Foods that scored 4 points or more and beverages that scored 1 point or more were categorized as 'less healthy'. A quarter (24.6\%) of display ads could not be classified using the PAHO and UK NPM because they featured either a brand name or a logo (14.2\%) or were categorized as unspecified (10.4\%). Alcoholic beverages were also excluded from the nutritional analysis.

\section{Statistical analysis}

Statistical analyses were conducted using the statistical software package IBM SPSS Statistics for Windows version 24 in January 2016. The number and frequency of ads appearing on all ten child-preferred websites in Canada from June 2015 to May 2016 were determined by company and food category. The nutritional information of advertised products and their classification by the PAHO and the UK NPM were weighted by the total number of ad impressions (i.e. the total number of times the ad appeared across all ten websites). The nutritional quality of products advertised during the examined year as classified by the NPM was described for the total sample, by CAI membership and for individual CAI companies using frequencies. The level of processing (unprocessed and processed $v$. ultra-processed) and the nutritional quality of CAI and non-CAI ads as classified by the PAHO NPM 
(excessive $v$. not excessive) and the UK NPM (healthier $v$. less healthy) were compared using Pearson $\chi^{2}$ tests. When differences were statistically significant, logistic regressions were conducted and OR were reported to describe the effect size (i.e. the magnitude of the difference between CAI and nonCAI companies). In addition, the nutrient content per $100 \mathrm{~g}$ serving of food product advertised by CAI and non-CAI companies was compared using independent $t$ tests. When differences were statistically significant, correlation coefficients ( $r$ ) were calculated to determine the effect size using the following formula ${ }^{(32)}: r=\sqrt{t^{2} / t^{2}+d f}$, where $t=t$ statistic and $d f=$ degrees of freedom.

The nutritional comparisons between CAI and non-CAI companies described above was carried out for ads appearing on all ten websites and those appearing on the six websites on which the CAI voluntary pledges apply (i.e. those with a child composition share of $35 \%$ or more). The significance level was set at $\alpha=0.01$ for all analyses.

\section{Results}

\section{Frequency of food/beverage display ads}

A total of 54003425 food ads appeared on children's preferred websites from June 2015 to May 2016 in Canada. CAI companies were responsible for 35449136 display ads $(65.6 \%)$, whereas non-CAI companies were responsible for 18554289 (34.4\%) ads. In other words, CAI companies were responsible for nearly twice as many display ads as non-CAI companies. roblox.com accounted for the majority (80.4\%) of ads viewed on all websites followed by coolmath-games.com (9.3\%) and kizi.com (7.7\%; data not shown)

As shown in Table 2, the food categories most frequently advertised overall were restaurants (32.0\%), cakes, cookies and ice cream (25.6\%), and cold cereal (11.4\%). Among CAI-company ads, the most frequently advertised food categories in descending order were cakes, cookies and ice cream (38.5\%), cold cereal (17.1\%) and restaurants (16.6\%). Among non-CAI company ads, more than half of the ads were for restaurants (62.4\%), followed by sugar-sweetened beverages (13.4\%) and alcohol $(7 \cdot 1 \%)$. Overall, the most frequently advertised products in order of importance were Kellogg's Pop Tarts (23.6\% of total ads), Kellogg's Frosted Flakes (9.3\%), McDonald's Happy Meal (6.8\%), Red Bull Energy Drink (2.8\%) and Kraft Lunchables (2.6\%). The ad creatives for these five products are available in the online supplementary material.

In the total sample, Kellogg's was responsible for more than a third (37.0\%) of all ads viewed on children's preferred websites from June 2015 to May 2016, followed by McDonalds (10.6\%) and Restaurant Brand International (7.9\%; Table 3). Of CAI-company ads, Kellogg's accounted for more than half $(56.4 \%)$ followed by McDonald's (16.2\%) and Kraft (10.7\%). Among non-CAI ads, companies who advertised the most were Restaurant Brand International (23.1\%), Red Bull (9.4\%) and St. Hubert BBQ (9.2\%).

\section{Nutritional quality of display ads on all ten children's preferred websites}

Overall, 92.7\% ( $n 32493191$ ) of food products advertised on the children's preferred websites were ultra-processed, while 0.8 and $6.5 \%$ were processed or unprocessed, respectively. CAI-company ads were 2.5 times more likely to be ultra-processed ( $v$. unprocessed or processed) compared with non-CAI ads $\left(94.9 v .88 .2 \% ; \chi_{(1)}^{2}=7.4 \times 10^{5}\right.$, $P<0.001$, OR $=2.5,99 \%$ CI 2.5, 2.5; data not shown). According to independent $t$ tests, there were statistically significant differences between the average nutrient content of CAI and non-CAI products advertised (Table 4). Among differences of larger magnitude, CAI products advertised contained more energy (mean difference $(\mathrm{MD})=141$, $99 \%$

Table 2 Number of food/beverage display ads per year on all ten children's preferred websites by food category and participation in the Canadian Children's Food and Beverage Advertising Initiative (CAI), June 2015-May 2016

\begin{tabular}{|c|c|c|c|c|c|c|}
\hline \multirow[b]{2}{*}{ Food category } & \multicolumn{2}{|c|}{ CAl companies } & \multicolumn{2}{|c|}{ Non-CAl companies } & \multicolumn{2}{|c|}{ Total } \\
\hline & $n$ & $\%$ & $n$ & $\%$ & $n$ & $\%$ \\
\hline Cakes, cookies and ice cream & 13296243 & 38.5 & 21000 & 0.1 & 13317243 & $25 \cdot 6$ \\
\hline Cold cereal & 5923170 & $17 \cdot 1$ & 28000 & 0.2 & 5951170 & 11.4 \\
\hline Mixed category & 1235282 & $3 \cdot 6$ & 502000 & 2.9 & 1737282 & $3 \cdot 3$ \\
\hline Tea or coffee & 968599 & $2 \cdot 8$ & 654609 & 3.7 & 1623208 & $3 \cdot 1$ \\
\hline Candy and chocolate & 1391872 & $4 \cdot 1$ & 0 & 0.0 & 1573498 & $3 \cdot 0$ \\
\hline Other & 336058 & $1 \cdot 0$ & 1161531 & $6 \cdot 6$ & 1497589 & 2.9 \\
\hline Alcohol & 0 & 0.0 & 1240246 & $7 \cdot 1$ & 1240246 & $2 \cdot 4$ \\
\hline Cheese & 939842 & $2 \cdot 7$ & 8000 & $<0.1$ & 947842 & 1.8 \\
\hline Water & 256198 & 0.7 & 0 & 0.0 & 256198 & 0.5 \\
\hline Total & 34538267 & $100 \cdot 0$ & 17579934 & $100 \cdot 0$ & 52118201 & $100 \cdot 0$ \\
\hline
\end{tabular}




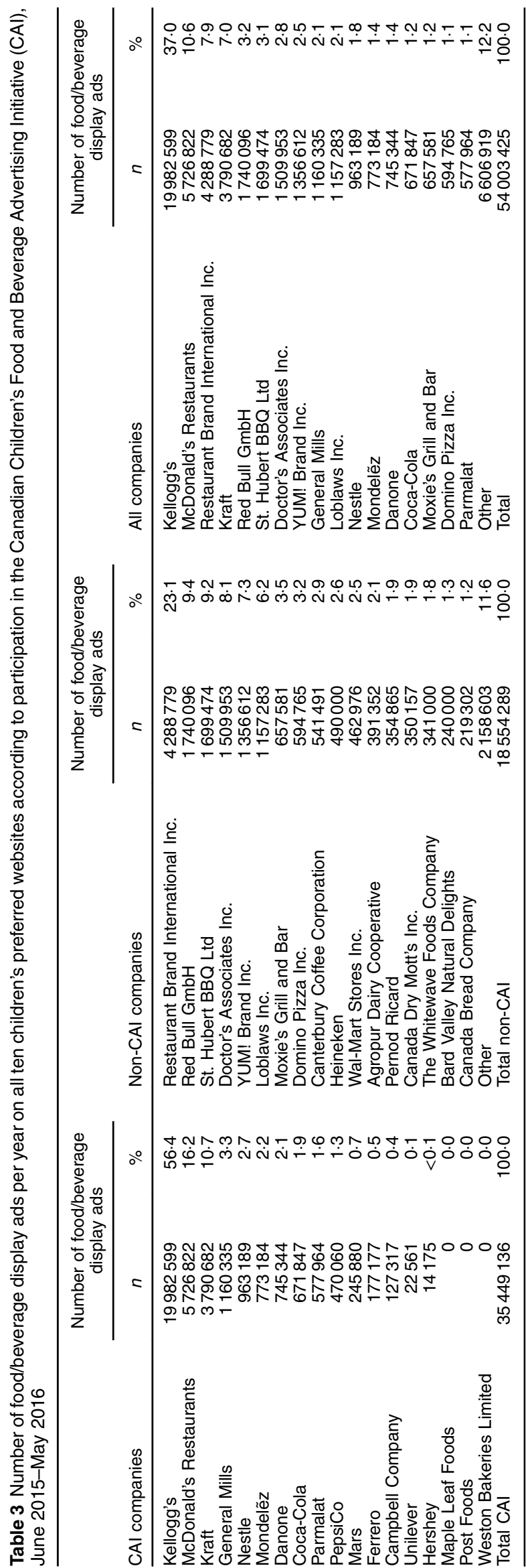

CI $141.1,141.4 \mathrm{kcal}, P<0.001, r=0.55)$, carbohydrates (MD $=39 \cdot 2,99 \%$ CI 39.2, 39.3 g, $P<0 \cdot 001, r=0 \cdot 71)$, sugar $(\mathrm{MD}=18.2,99 \%$ CI $18.2,18.2 \mathrm{~g}, P<0.001, r=0.68)$ and $\mathrm{Na}(\mathrm{MD}=70 \cdot 0,99 \% \mathrm{CI} 69 \cdot 7,70 \cdot 2 \mathrm{mg}, P<0 \cdot 001, r=0.23)$ per $100 \mathrm{~g}$ serving than products advertised by non-CAI companies.

The vast majority of ads (93.4\%) were categorized as excessive in fat, $\mathrm{Na}$ or free sugars according to the PAHO NPM and $73.8 \%$ of ads were categorized as 'less healthy' according to the UK NPM (Table 5). Products advertised by CAI companies were less likely to be excessive in total fat $(10.7 v .52 \cdot 7 \% ; P<0.001 ; \mathrm{OR}=0.11)$, saturated fat $(16.8$ v. $45.5 \% ; P<0.001 ; \mathrm{OR}=0.24)$, trans-fat $(4.1 v .7 \cdot 1 \%$; $P<0.001 ; \mathrm{OR}=0.56)$ and $\mathrm{Na}(39.7$ v. $56.2 \% ; P<0.001 ;$ $\mathrm{OR}=0.51)$ compared with those advertised by non-CAI companies. On the other hand, CAI product ads were more likely to be excessive in free sugars (89.0 v. 40.5\%; $P<0.001, \mathrm{OR}=11.9)$ or in at least one nutrient $(94.7 v$. $89.3 \% ; P<0.001 ; \mathrm{OR}=2.15)$ as well as to be categorized as 'less healthy' (78.4 v. 59.0\%; $P<0.001 ; \mathrm{OR}=2.53)$ compared with non-CAI product ads.

As shown in Table 6, all (100\%) Campbell, Coca-Cola, Danone, Ferrero, General Mills, Kellogg's, McDonald's, Nestlé, Parmalat and PepsiCo ads on children's preferred websites were for products classified as excessive in total fat, saturated fat, trans-fat, Na or free sugars. More than $90 \%$ of Campbell, Coca-Cola, Danone, Ferrero, Kellogg's, McDonald's and PepsiCo products advertised were classified as excessive in free sugars, while 99\% of McDonald's and $100 \%$ of Parmalat's advertised products were classified as excessive in Na. Furthermore, all (100\%) Campbell, Ferrero, Parmalat and PepsiCo products advertised were categorized as 'less healthy'.

\section{Nutritional quality of display ads on the six websites on which the Canadian Children's Food and Beverage Advertising Initiative commitments apply}

Most ads (93.8\%) on the six websites on which the CAI applies were categorized as excessive in fat, $\mathrm{Na}$ or free sugars according to the PAHO NPM and $72.9 \%$ of ads were categorized as 'less healthy' according to the UK NPM (data not shown). Products advertised by CAI companies were significantly less likely to be excessive in total fat (10.8 v. 53.5\%; $P<0 \cdot 001 ; \mathrm{OR}=0 \cdot 10,99 \% \mathrm{CI} 0 \cdot 10,0 \cdot 11)$, saturated fat $(17 \cdot 7 v$. $46.0 \% ; P<0.001 ; \mathrm{OR}=0.25,99 \% \mathrm{CI} 0.25,0.25)$, trans-fat $(4.2$ v. $6.4 \% ; P<0.001 ; \mathrm{OR}=0.64,99 \% \mathrm{CI} 0.63,0.64)$ and $\mathrm{Na}(43.5$ v. $56.8 \% ; P<0.001 ; \mathrm{OR}=0.59,99 \%$ CI $0.58,0.59)$ compared with those advertised by non-CAI companies. Conversely, CAI product ads were significantly more likely to be excessive in free sugars (90.0 v. 41.0\%; $P<0 \cdot 001$; OR $=13 \cdot 0,99 \%$ CI $13 \cdot 0$, $13 \cdot 1)$ or in at least one nutrient $(95.2 v$. 89.8; $P<0 \cdot 001 ; \mathrm{OR}=$ $2 \cdot 3,99 \%$ CI $2 \cdot 2,2 \cdot 3)$ as well as categorized as 'less healthy' $(77.5$ v. 59.3\%; $P<0.001 ; \mathrm{OR}=2.4,99 \%$ CI $2 \cdot 4,2.4)$ compared with non-CAI product ads. In addition, CAI product ads on these six websites also contained more energy $(\mathrm{MD}=139$, $99 \%$ CI 138.7, $139.0 \mathrm{kcal}, P<0 \cdot 001, r=0.53)$, carbohydrates 
Table 4 Average nutrient content per $100 \mathrm{~g}$ of food/beverage products advertised on children's preferred websites according to participation in the Canadian Children's Food and Beverage Advertising Initiative (CAI), June 2015-May 2016

\begin{tabular}{|c|c|c|c|c|c|c|c|c|c|c|c|}
\hline & \multicolumn{2}{|c|}{ CAI companies } & \multicolumn{2}{|c|}{ Non-CAI companies } & \multirow[b]{2}{*}{ MD } & \multirow[b]{2}{*}{$99 \% \mathrm{Cl}$} & \multirow[b]{2}{*}{$t$} & \multirow[b]{2}{*}{ df } & \multirow[b]{2}{*}{$r$} & \multicolumn{2}{|c|}{ Total } \\
\hline & Mean & SD & Mean & SD & & & & & & Mean & SD \\
\hline Energy (kcal)† & 328.0 & $129 \cdot 0$ & $186 \cdot 7$ & $162 \cdot 9$ & $141 \cdot 2$ & $141 \cdot 1,141 \cdot 4$ & $-2508 \cdot 02^{\star \star \star}$ & $1.45 \times 10^{7}$ & 0.55 & 292.9 & $151 \cdot 1$ \\
\hline Total fat $(\mathrm{g})$ & $7 \cdot 8$ & 7.5 & $7 \cdot 3$ & $12 \cdot 4$ & 0.5 & $0.48,0.51$ & $-119 \cdot 54^{\star \star \star}$ & $1.26 \times 10^{7}$ & 0.03 & $7 \cdot 7$ & 9.0 \\
\hline Saturated fat (g) & $2 \cdot 7$ & 3.3 & 2.9 & $8 \cdot 7$ & -0.1 & $-0.17,-0.16$ & $59.98^{\star \star \star}$ & $1.11 \times 10^{7}$ & 0.02 & $2 \cdot 7$ & $5 \cdot 2$ \\
\hline Trans-fat (g) & 0.04 & 0.14 & 0.07 & 0.11 & -0.03 & $-0.0351,-0.0349$ & $828 \cdot 88^{\star \star \star}$ & $2.18 \times 10^{7}$ & 0.17 & 0.05 & 0.13 \\
\hline $\mathrm{Na}(\mathrm{g})$ & $316 \cdot 2$ & $166 \cdot 9$ & $246 \cdot 3$ & $244 \cdot 1$ & $70 \cdot 0$ & $69 \cdot 7,70 \cdot 2$ & $-847 \cdot 38^{\star \star \star}$ & $1.33 \times 10^{7}$ & 0.23 & 298.9 & 191.5 \\
\hline Carbohydrates (g) & 59.6 & $27 \cdot 8$ & $20 \cdot 4$ & $18 \cdot 6$ & $39 \cdot 2$ & $39 \cdot 2,39 \cdot 3$ & $-5084 \cdot 39^{\star \star \star}$ & $2.58 \times 10^{7}$ & 0.71 & $49 \cdot 9$ & 30.9 \\
\hline Fibre $(\mathrm{g})$ & 1.9 & $4 \cdot 0$ & $1 \cdot 1$ & 1.5 & 0.8 & $0.759,0.763$ & $-877 \cdot 53^{\star \star \star}$ & $4.00 \times 10^{7}$ & 0.14 & 1.7 & 3.6 \\
\hline Sugar (g) & $26 \cdot 4$ & $13 \cdot 2$ & 8.2 & $12 \cdot 4$ & $18 \cdot 2$ & $18 \cdot 19,18 \cdot 22$ & $-3991 \cdot 37^{\star \star \star}$ & $1.83 \times 10^{7}$ & 0.68 & 21.9 & $15 \cdot 2$ \\
\hline Protein (g) & $5 \cdot 1$ & 2.9 & $5 \cdot 8$ & 4.9 & -0.7 & $-0.69,-0.68$ & $421 \cdot 32^{\star \star \star}$ & $1.24 \times 10^{7}$ & 0.12 & $5 \cdot 3$ & 3.5 \\
\hline
\end{tabular}

$\mathrm{MD}$, mean difference.

${ }^{\star \star \star *} P<0.001$.

†To convert to kJ, multiply kcal value by $4 \cdot 184$.

Table 5 Number and percentage of food/beverage products on children's top ten preferred websites by nutritional quality and participation in the Canadian Children's Food and Beverage Advertising Initiative (CAI), June 2015-May 2016

\begin{tabular}{|c|c|c|c|c|c|c|c|c|c|c|}
\hline & \multicolumn{2}{|c|}{ CAI companies } & \multicolumn{2}{|c|}{ Non-CAI companies } & \multirow[b]{2}{*}{$x^{2}$} & \multirow[b]{2}{*}{ df } & \multirow[b]{2}{*}{ OR† } & \multirow[b]{2}{*}{$99 \% \mathrm{Cl}$} & \multicolumn{2}{|l|}{ Total } \\
\hline & $n$ & $\%$ & $n$ & $\%$ & & & & & $n$ & $\%$ \\
\hline Excessive in total fat & 3256000 & $10 \cdot 7$ & 5109043 & $52 \cdot 7$ & $7.9 \times 10^{6 * \star *}$ & 1 & 0.11 & $0.11,0.11$ & 8365043 & $20 \cdot 8$ \\
\hline Excessive in saturated fat & 5120000 & $16 \cdot 8$ & 4409043 & $45 \cdot 5$ & $3.4 \times 10^{6 * \star *}$ & 1 & 0.24 & $0.24,0.24$ & 9529043 & 23.7 \\
\hline Excessive in trans-fat & 1249000 & 4.1 & 688000 & $7 \cdot 1$ & $1.5 \times 10^{5 * \star *}$ & 1 & 0.56 & $0.56,0.56$ & 1937000 & 4.8 \\
\hline Excessive in $\mathrm{Na}$ & 12141000 & 39.7 & 5446147 & $56 \cdot 2$ & $8.1 \times 10^{5 * \star *}$ & 1 & 0.51 & $0.51,0.51$ & 17587147 & 43.7 \\
\hline Excessive in free sugars & 27219000 & $89 \cdot 0$ & 3924000 & 40.5 & $9.9 \times 10^{6 * * *}$ & 1 & 11.9 & $11.9,12.0$ & 31143000 & 77.4 \\
\hline Excessive in at least one nutrient & 28949000 & 94.7 & 8649190 & $89 \cdot 3$ & $3.5 \times 10^{5 * * *}$ & 1 & 2.15 & $2 \cdot 14,2 \cdot 16$ & 37598190 & 93.4 \\
\hline Less healthy (UK NPM) & 23979000 & 78.4 & 5720043 & $59 \cdot 0$ & $1.4 \times 10^{6 * * *}$ & 1 & 2.53 & $2.52,2.53$ & 29699043 & 73.8 \\
\hline
\end{tabular}

UK NPM, UK Nutrient Profile Model.

${ }_{* * *}^{*} P<0.001$.

†Reference group: non-CAI companies.

Table 6 Number and percentage of food/beverage ads of individual companies participating in the Canadian Children's Food and Beverage Advertising Initiative (CAl) classified as less healthy or excessive in fat, sodium or free sugars on children's top ten preferred websites, June 2015-May 2016

\begin{tabular}{|c|c|c|c|c|c|c|c|c|c|c|c|c|c|c|}
\hline \multirow[b]{2}{*}{ CAI companies } & \multicolumn{2}{|c|}{$\begin{array}{l}\text { Excessive in } \\
\text { total fat }\end{array}$} & \multicolumn{2}{|c|}{$\begin{array}{l}\text { Excessive in } \\
\text { saturated fat }\end{array}$} & \multicolumn{2}{|c|}{$\begin{array}{l}\text { Excessive in } \\
\text { trans-fat }\end{array}$} & \multicolumn{2}{|c|}{ Excessive in $\mathrm{Na}$} & \multicolumn{2}{|c|}{$\begin{array}{l}\text { Excessive in free } \\
\text { sugars }\end{array}$} & \multicolumn{2}{|c|}{$\begin{array}{l}\text { Excessive in at } \\
\text { least one nutrient }\end{array}$} & \multicolumn{2}{|c|}{$\begin{array}{l}\text { Less healthy } \\
\text { (UK NPM) }\end{array}$} \\
\hline & $n$ & $\%$ & $n$ & $\%$ & $n$ & $\%$ & $n$ & $\%$ & $n$ & $\%$ & $n$ & $\%$ & $n$ & $\%$ \\
\hline $\begin{array}{l}\text { Campbell } \\
\text { Company }\end{array}$ & 74000 & $67 \cdot 9$ & 74000 & 67.9 & 0 & 0.0 & 36000 & 33.0 & 108000 & $99 \cdot 1$ & 109000 & $100 \cdot 0$ & 109000 & $100 \cdot 0$ \\
\hline Coca-Cola & 0 & 0.0 & 0 & 0.0 & 0 & 0.0 & 0 & 0.0 & 517000 & $100 \cdot 0$ & 517000 & $100 \cdot 0$ & 95000 & $18 \cdot 4$ \\
\hline Danone & 2000 & 0.3 & 527000 & 87.8 & 2000 & 0.3 & 0 & 0.0 & 598000 & 99.7 & 600000 & $100 \cdot 0$ & 52000 & $8 \cdot 7$ \\
\hline Ferrero & 18000 & $20 \cdot 9$ & 18000 & 20.9 & 0 & 0.0 & 0 & 0.0 & 86000 & $100 \cdot 0$ & 86000 & $100 \cdot 0$ & 86000 & $100 \cdot 0$ \\
\hline General Mills & 6000 & $28 \cdot 6$ & 6000 & $28 \cdot 6$ & 15000 & 71.4 & 15000 & 71.4 & 6000 & $28 \cdot 6$ & 21000 & $100 \cdot 0$ & 15000 & 71.4 \\
\hline Hershey & & 0.0 & 0 & 0.0 & 0 & 0.0 & 0 & 0.0 & 0 & 0.0 & 0 & 0.0 & 0 & 0.0 \\
\hline Kellogg's & 1235000 & $6 \cdot 2$ & 1235000 & $6 \cdot 2$ & 0 & 0.0 & 5362000 & $26 \cdot 9$ & 19874000 & 99.8 & 19912000 & $100 \cdot 0$ & 19863000 & 99.8 \\
\hline Kraft & 507000 & $17 \cdot 3$ & 1731000 & $59 \cdot 2$ & 337000 & 11.5 & 2050000 & $70 \cdot 1$ & 1400000 & 47.9 & 2056000 & $70 \cdot 3$ & 1895000 & 64.8 \\
\hline $\begin{array}{l}\text { Maple Leaf } \\
\text { Foods Inc. }\end{array}$ & - & & - & & - & & - & & - & & - & & - & \\
\hline Mars & 1000 & 0.6 & 1000 & 0.6 & 0 & 0.0 & 6000 & 3.6 & 4000 & 2.4 & 10000 & 5.9 & 4000 & $2 \cdot 4$ \\
\hline $\begin{array}{l}\text { McDonald's } \\
\text { Restaurants }\end{array}$ & 365000 & 8.9 & 366000 & 8.9 & 25000 & 0.6 & 4023000 & $98 \cdot 3$ & 3697000 & $90 \cdot 3$ & 4060000 & $99 \cdot 2$ & 364000 & 8.9 \\
\hline Mondelẽz & 14000 & 2.5 & 13000 & $2 \cdot 3$ & 0 & 0.0 & 1000 & 0.2 & 13000 & $2 \cdot 3$ & 14000 & 2.5 & 14000 & 2.5 \\
\hline Nestlé & 476000 & 74.0 & 591000 & 91.9 & 312000 & 48.5 & 90000 & $14 \cdot 0$ & 553000 & $86 \cdot 0$ & 643000 & $100 \cdot 0$ & 561000 & 87.2 \\
\hline Parmalat & 558000 & $100 \cdot 0$ & 558000 & $100 \cdot 0$ & 558000 & $100 \cdot 0$ & 558000 & $100 \cdot 0$ & 0 & 0.0 & 558000 & $100 \cdot 0$ & 558000 & $100 \cdot 0$ \\
\hline $\begin{array}{l}\text { PepsiCo } \\
\text { Post Foods }\end{array}$ & $\begin{array}{r}0 \\
-\end{array}$ & 0.0 & $\begin{array}{r}0 \\
-\end{array}$ & 0.0 & $\begin{array}{r}0 \\
-\end{array}$ & 0.0 & $\begin{array}{r}0 \\
-\end{array}$ & 0.0 & 363000 & $100 \cdot 0$ & $\begin{array}{c}363000 \\
-\end{array}$ & $100 \cdot 0$ & $\begin{array}{c}363000 \\
-\end{array}$ & 100.0 \\
\hline Unilever & 0 & 0.0 & 0 & 0.0 & 0 & 0.0 & 0 & 0.0 & 0 & 0.0 & 0 & 0.0 & 0 & 0.0 \\
\hline $\begin{array}{l}\text { Weston } \\
\text { Bakeries } \\
\text { Limited }\end{array}$ & - & & - & & - & & - & & - & & - & & - & \\
\hline Total CAI & 3256000 & $10 \cdot 7$ & 5120000 & $16 \cdot 8$ & 1249000 & $4 \cdot 1$ & 12141000 & 39.7 & 27219000 & 89.0 & 28949000 & 94.7 & 23979000 & 78.4 \\
\hline
\end{tabular}

UK NPM, UK Nutrient Profile Model. 
$(\mathrm{MD}=39 \cdot 8, \quad 99 \% \quad \mathrm{CI} \quad 39 \cdot 7, \quad 39.8 \mathrm{~g}, \quad P<0.001, \quad r=0.70)$, sugar (MD $=18.5,99 \%$ CI 18.5, 18.5 g, $P<0.001, r=0.68)$ and $\mathrm{Na}(\mathrm{MD}=72,99 \% \mathrm{CI} 71.7,72 \cdot 1 \mathrm{mg}, P<0 \cdot 001, r=0.23)$ per $100 \mathrm{~g}$ serving than products advertised by non-CAI companies (data not shown).

\section{Discussion}

In summary, there were approximately 54 million food display ads on children's top ten preferred websites in Canada between June 2015 and May 2016. More than nine out of ten products advertised were ultra-processed with the most frequently advertised food categories being restaurants, cakes, cookies and ice cream, and cold cereal. Overall, the nutritional quality of advertised foods was poor, as over $90 \%$ of ads were found to be excessive in fat, $\mathrm{Na}$ or free sugars according to the PAHO NPM and about $74 \%$ were deemed 'less healthy' according to the UK NPM. These results mirror what has been seen on television advertising in Canada ${ }^{(12)}$. This high frequency of unhealthy food pop-up and banner ads also points to the failure of self-regulation in limiting food advertising that is high in fat, $\mathrm{Na}$ and sugar on children's preferred websites in Canada.

Although the present study did not systematically analyse the marketing techniques used in these digital ads, it is interesting to note that a large proportion of the five most advertised products, accounting for $45 \%$ of total ads on all ten websites, featured advertising techniques that expressly appeal to children, including, among others: the use of branded or licenced characters (e.g. Frosted Flakes and McDonald's Happy Meal), the promotion of a prize giveaway (e.g. Pop Tarts) and the use of cartoons and animation (e.g. Red Bull energy drink and Lunchables).

\section{Advertising behaviour of companies participating in the Canadian Children's Food and Beverage Advertising Initiative}

CAI companies were responsible for nearly twice as many displays ads as non-CAI companies and the nutritional quality of their advertised products was also arguably worse. Indeed, even though products advertised by CAI companies were less likely to be excessive in fat and $\mathrm{Na}$, their ads overall were more than two times more likely to be excessive in fat, $\mathrm{Na}$ or free sugars or deemed 'less healthy' compared with non-CAI ads. These results are largely driven by the fact that CAI ads more often featured products that were energydense and excessive in free sugars. These findings were similar when we exclusively examined the six of the ten websites on which the CAI commitments are supposed to apply (i.e. those with a child composition share of $\geq 35 \%$ ). Such results are consistent with research on food advertising on television in Canada ${ }^{(13,33)}$ and on children's preferred websites in the $\mathrm{USA}^{(34)}$, whereby companies who are voluntarily pledging to limit unhealthy food advertising to children are in fact among the worst offenders.
It should be noted, however, that the behaviour of individual CAI companies on children's preferred websites varied greatly. For example, three companies alone including Kellogg's, McDonald's and Kraft were collectively responsible for $83 \%$ of all CAI ads featured on all websites while other companies advertised very little in comparison. Three CAI companies including Maple Leaf Foods, Post Foods and Weston Bakeries did not advertise at all.

Although we categorized ads according to the Canadian CAI membership, it should be noted that we could not necessarily attribute these ads to Canadian companies as this information was not always specified in the ad creatives (i.e. the actual advertisement). In some cases, we could directly credit some advertisements to Canadian CAI companies such as Kellogg's (e.g. Froot Loops, Frosted Flakes), McDonald's (e.g. Happy Meal, Chicken Bacon Onion burger, Big Mac), Danone (e.g. Danette pudding), Parmalat (e.g. Black Diamond cheese spread), Ferrero (e.g. Tic Tac Mixers), Nestlé (e.g. Smarties) and Mars (e.g. Uncle Ben's brand) as ads were either bilingual (English and French, the official languages of Canada) or specifically mentioned Canada (see online supplementary material). Although in most instances we could not make the distinction between Canadian and American company ads, it should be noted that fifteen of the eighteen companies participating in the CAI in Canada are also participating in the initiative in the USA and significant similarities exists between pledges made by companies on either side of the border ${ }^{(25,26)}$. Our inability to clearly identify ads by country of origin highlights one of the challenges faced by countries attempting to regulate digital food and beverage marketing to children. To ensure the success of digital food and beverage marketing restrictions online, international cooperation and treaties such as that developed in the tobacco prevention field (e.g. the WHO Framework Convention on Tobacco Control) will likely be essential $^{(35)}$.

\section{Nutrient profiling}

We assessed the nutritional quality of products advertised using two nutrient profile models. In some instances, there were great disparities in how these models characterized the healthfulness of products. The difference is particularly evident when examining the overall healthfulness of products advertised by three CAI companies, namely Coca-Cola, Danone and McDonald's. This discrepancy is partly due to the fact the UK NPM considers positive nutrients, allowing some foods containing moderate or high amounts of fibre, vegetables, fruit and nuts, and/or protein to be deemed healthier even though they are high in one or more 'negative' nutrients such as $\mathrm{Na}$, saturated fat or sugar. For instance, this was the case for sweetened yoghurt and pudding advertised by Danone for which free sugars accounted for about 20 and $40 \%$ of total energy, respectively. McDonald's Happy Meal was also deemed 
'healthier' by the UK NPM despite containing excessive amounts of $\mathrm{Na}$.

Nutrient profiling using negative nutrients may be a better approach for determining which products should not be advertised to children as the content in positive nutrients (such as protein) does not cancel out the effect of negative ones (e.g. Na, sugar and saturated fat). The UK NPM is in fact currently being revised as some nutrient limits, such as for sugar, do not meet current dietary guidelines ${ }^{(36)}$.

\section{Alcohol and caffeinated energy drink advertising}

In many Canadian provinces, advertising of alcohol is prohibited on websites or any mediums that specifically target minors ${ }^{(37,38)}$. Many alcohol producers also have internal advertising codes and/or participate in voluntarily pledges to abstain from advertising on websites where minors make up $30 \%$ or more of their visitors, unless the website features a screening process requiring visitors to provide their age (also known as age-gating) ${ }^{(39-41)}$. In our study, two companies, namely Bacardi Limited and Pernod Ricard, advertised on coolmath-games.com even though it does not have an agegating feature and minors (2-17 years) make up more than $65 \%$ of its visitors (comscore Media Metrix report, Males and females aged 2-18 years old (All regions excluding Quebec), March-May 2016). These two companies in addition to five others also advertised on roblox.com although this website requires users to provide their age when creating an account. Our results suggest that children may be exposed to alcohol advertising on their preferred websites despite provincial regulations/rules prohibiting such marketing. Other studies have documented the exposure of youth to alcohol advertising online ${ }^{(42)}$ and have questioned the effectiveness of age-gating in protecting children from the marketing of alcoholic beverages ${ }^{(43,44)}$. This is concerning given that several longitudinal studies have found that youth exposure to such advertising is associated with underage drinking ${ }^{(45,46)}$. Another finding of interest was that, despite rules against the promotion of caffeinated energy drinks to children in Canada ${ }^{(47)}$, Red Bull, one of the most advertised products on children's preferred websites, was also advertised on roblox.com and coolmath-games.com. This is equally worrisome given that the consumption of energy drinks by children is not recommended because many adverse physical and behavioural side-effects have been reported among youth as a result of consuming these beverages $^{(48,49)}$. Obviously, systematic monitoring of both alcohol and caffeinated energy drinks advertising online is clearly needed in Canada to protect children.

\section{Policy implications}

A bill restricting unhealthy food and beverage marketing to children under the age of 17 years has recently been passed by the Senate of Canada and is currently under review by the House of Commons ${ }^{(50)}$. This bill will likely be passed in early 2018 and afterwards Health Canada is expected to propose regulations to accompany the bill ${ }^{(51)}$. Contrary to the approach endorsed by more than fifty health organizations including The Heart and Stroke Foundation, the Canadian Medical Association and Dietitians of Canada, the government is leaning towards restricting the marketing of products that are high in saturated fat, $\mathrm{Na}$ or sugar rather than apply the ban to all foods ${ }^{(52,53)}$. This approach could potentially create a loophole allowing companies to promote brands that are largely associated with unhealthy products rather than advertise specific products. In our study, for instance, about 7.6 million display ads promoted brands of which $78 \%$ were for fast-food restaurants or ultra-processed foods (data not shown). It is thus essential when governments develop policy in this area that brands that frequently target children be included in the definition of unhealthy food marketing.

The limited number of websites that met our selection criteria also highlights the limitation of using the composition of child visitors as the sole criterion to identify child-targeted websites. Indeed, our study identified only thirty-seven websites where children made up at least $15 \%$ of visitors and who reached a minimum of 50000 children aged 2-11 years (which is equivalent to only $1.7 \%$ of Internet users of this age group; comScore Media Metrix report, 2-11 age group (Canada), March-May 2016). Websites that appeal to a broader audience (e.g. children, teens and adults) may reach a greater number of children but may fall short of child visitor composition thresholds as high as $25-35 \%$. This is the case with social media websites on which youth are exposed to various forms of marketing, including video and display advertising and user-generated and viral/word-of-mouth marketing ${ }^{(54)}$. Furthermore, digital marketing restrictions based on child composition thresholds alone fail to acknowledge the sophistication with which marketers can target their desired demographic online (i.e. by using behavioural targeting) given the mass quantity of metadata being collected on the behaviours of Internet users, including children $^{(55,50)}$.

To date, it is unclear if and how Canada's future legislation will address cross-border digital food and beverage marketing. Given the borderless nature of the Internet, a recent WHO report highlighted the need for coordinated regulations across multiple countries to effectively limit children's exposure to digital food and beverage marketing ${ }^{(55)}$. Our findings add to the growing body of evidence exposing how food and beverage companies market to children and youth online ${ }^{(17-19,22,23,54)}$, further justifying the calls to coordinate globally at the highest level to protect children from such marketing ${ }^{(55)}$.

\section{Strengths and limitations}

The present study is the first to examine the frequency and nutritional quality of food ads on child-targeted third-party websites in Canada. The study used data from comScore, which has the largest panel of Internet users in the country and constitutes the best available information on the use of digital media and the frequency of display advertising. Although the accuracy of comscore's data is unknown, 
these data are used by large food and beverage companies to make advertising decisions. Other strengths include the examination of ads over an entire year, which avoids any biases related to seasonal variation in ad spending, and the use of two nutrient profile models to assess the healthfulness of advertised products. In terms of limitations, the study examined only the display advertising on ten websites and did not include video ads. Consequently, results may underrepresent the total frequency of food advertising on all childtargeted websites. Due to behavioural targeting, it is also difficult to determine children's individual exposure to food advertising on these websites. Even though comScore offers a service allowing advertisers, including food and beverage companies, to measure the success of their live online advertising campaigns in reaching their desired demographic $^{(57)}$, segmented advertising exposure data are not otherwise available. Despite not having access to such data, which constitutes a great challenge globally for public health researchers examining digital food and beverage marketing $^{(55)}$, it should be noted that the ad creatives of the five most advertised products alone reveal the explicit intent of some companies to target children.

\section{Conclusion}

The current study adds to the overwhelming evidence that self-regulation in Canada has not been effective in protecting children against the advertising of unhealthy foods, including in digital media on their preferred websites. Mandatory regulations adapted to the modern digital environment are needed to protect children's health.

\section{Acknowledgements}

Financial support: This research was funded by The Heart and Stroke Foundation and Toronto Public Health. These organizations had no role in the design, analysis or writing of this article. Conflict of interest: None to declare. Authorship: M.P.K. designed the study and oversaw the data collection and analysis. E.P. collected and analysed the data and wrote the first draft of the manuscript. Both authors reviewed and approved the final manuscript. Etbics of buman subject participation: Not applicable.

\section{Supplementary material}

To view supplementary material for this article, please visit https://doi.org/10.1017/S1368980017004177

\section{References}

1. Ng M, Fleming T, Robinson M et al. (2014) Global, regional, and national prevalence of overweight and obesity in children and adults during 1980-2013: a systematic analysis for the Global Burden of Disease Study. Lancet 384, 766-781.

2. Janssen I (2013) The public health burden of obesity in Canada. Can J Diabetes 37, 90-96.
3. McGinnis JM, Gootman J \& Kraak VI (editors) (2006) Food Marketing to Children and Youth: Threat or Opportunity? Washington, DC: The National Academies Press.

4. Hastings G, McDermott L, Angus K et al. (2006) The Extent, Nature and Effects of Food Promotion to Children: A Review of the Evidence. Geneva: WHO.

5. Cairns G, Angus K, Hastings G et al. (2013) Systematic reviews of the evidence on the nature, extent and effects of food marketing to children. A retrospective summary. Appetite 62, 209-215.

6. Sadeghira B, Duhaney T, Motaghipisheh S et al. (2016) Influence of unhealthy food and beverage marketing on children's dietary intake and preference: a systematic review and meta-analysis of randomized trials. Obes Rev 17, 945-959.

7. World Health Organization (2010) Set of Recommendations on the Marketing of Foods and Non-Alcoholic Beverages to Children. Resolution of the Sixty-third World Health Assembly WHA63.14 Marketing of Food and Non-Alcoholic Beverages to Children. Geneva: WHO.

8. Advertising Standards Canada (2016) The Canadian Children's Food and Beverage Advertising Initiative. http:// www.adstandards.com/en/childrensinitiative/CCFBAI_EN. pdf (accessed February 2017).

9. Advertising Standards Canada (2017) The Canadian Children's Food and Beverage Advertising Initiative: 2016 Compliance Report. http://www.adstandards.com/ en/childrensinitiative/2016ComplianceReport.pdf (accessed November 2017).

10. Potvin Kent M, Dubois L \& Wanless A (2011) Food marketing on children's television in two different policy environments. Int J Pediatr Obes 6, e433-e441.

11. Kelly B, Halford JC, Boyland EJ et al. (2010) Television food advertising to children: a global perspective. Am J Public Health 100, 1730-1736.

12. Potvin Kent M, Dubois L \& Wanless A (2012) A nutritional comparison of foods and beverages marketed to children in two advertising policy environments. Obesity (Silver Spring) 20, 1829-1837.

13. Potvin Kent M, Martin C \& Kent EA (2014) Changes in the volume, power and nutritional quality of foods marketed to children on television in Canada 2006-2011. Obesity (Silver Spring) 22, 2053-2060.

14. Potvin Kent M \& Wanless A (2014) The influence of the Children's Food and Beverage Advertising Initiative: change in children's exposure to food advertising on television in Canada between 2006-2009. Int J Obes (Lond) 38, 558-562.

15. Powell LM, Harris JL \& Fox T (2013) Food marketing expenditures aimed at youth: putting the numbers in context. Am J Prev Med 45, 453-461.

16. Cai X \& Zhao X (2014) Click here kids! Online advertising practices on popular children's websites. J Child Media $\mathbf{4}$, 135-154.

17. Weber K, Story M \& Harnack L (2006) Internet food marketing strategies aimed at children and adolescents: a content analysis of food and beverage brand websites. $\mathrm{J} \mathrm{Am}$ Diet Assoc 106, 1463-1466.

18. Alvy LM \& Clavert SL (2006) Food marketing on popular children's web sites: a content analysis. J Am Diet Assoc 108, 710-713.

19. Kelly B, Bochynska K, Korman K et al. (2008) Internet food marketing on popular children's websites and food product websites in Australia. Public Health Nutr 11, 1180-1187.

20. Steeves V (2014) Young Canadians in a Wired World, Phase III: Life Online. Ottawa: Media Smarts.

21. Leatherdale ST \& Ahmed R (2011) Screen-based sedentary behaviours among a nationally representative sample of youth: are Canadian kids couch potatoes? Chronic Dis Inj Can 31, 141-146. 
22. Brady J, Mendelson R, Farrell A et al. (2010) Online marketing of foods and beverages to children: a content analysis. Can J Diet Pract Res 71, 166-171.

23. Potvin Kent M, Dubois L, Kent EA et al. (2013) Internet marketing directed at children on food and restaurant websites in two policy environments. Obesity (Silver Spring) 21, 800-807.

24. Office de la protection du consommateur (1978) Loi Sur La Protection du Consommateur. Québec: Gouvernement du Québec.

25. Council of Better Business Bureaus, Inc. (2014) Children's Food and Beverage Advertising Initiative: Program and Core Principles Statement, 4th edition. http://www.bbb.org/ globalassets/local-bbbs/council-113/media/cfbai/enhancedcore-principles-fourth-edition-with-appendix-a.pdf (accessed November 2017).

26. Council of Better Business Bureaus, Inc. (2017) Children's Food and Beverage Advertising Initiative: Foods and Beverages that Meet the CFBAI Category-Specific Uniform Nutrition Criteria that May be in Child-Directed Advertising. http://www.bbb.org/globalassets/shared/media/cfbai/cfbaiproduct-list-january-2017_final.pdf (accessed November 2017).

27. Pan American Health Organization (2016) Pan American Health Organization Nutrient Profile Model. Washington, DC: PAHO; available at http://iris.paho.org/xmlui/bitstream/handle/ 123456789/18621/9789275118733_eng.pdf?sequence=9

28. UK Department of Health (2011) Nutrient Profiling Technical Guidance January 2011. https://www.gov.uk/ government/uploads/system/uploads/attachment_data/file/ 216094/dh_123492.pdf (accessed February 2017).

29. Arambepola C, Scarborough P \& Rayner M (2008) Validating a nutrient profile model. Public Health Nutr 11, 371-378.

30. Scarborough P, Boxer A, Rayner M et al. (2007) Testing nutrient profile models using data from a survey of nutrition professionals. Public Health Nutr 10, 337-345.

31. Food Standards Agency (2012) Food Portion Sizes, 3rd ed. pp. 8-12. London: Food Standards Agency.

32. Fields A (2013) Discovering Statistics Using IBM SPSS Statistics, 4th ed. London: SAGE Publications Ltd.

33. Potvin Kent M, Dubois L \& Wanless A (2011) Self-regulation by industry of food marketing is having little impact during children's preferred television. Int J Pediatr Obes 6, 401-408.

34. Ustjanauskas AE, Harris JL \& Schwartz MB (2014) Food and beverage advertising on children's web sites. Pediatr Obes 9, 362-372

35. World Health Organization (2015) The WHO Framework Convention on Tobacco Control: An Overview. Geneva: WHO; available at http://www.who.int/fctc/about/WHO_ FCTC_summary_January2015.pdf?ua=1

36. Public Health England (2017) Review of the Nutrient Profiling Model. London: Public Health England; available at http://www.gov.uk/government/collections/review-of-thenutrient-profiling-model

37. Alcohol and Gaming Commission of Ontario (2016) Liquor Advertising Guidelines. http://www.agco.ca/sites/default/ files/3099_a.pdf (accessed February 2017).

38. Alberta Gaming and Liquor Commission (2017) Liquor Agency Handbook. http://www.aglc.ca/sites/aglc.ca/files/ 2017-08/Liquor\%20Agency\%20Handbook\%20August $\% 204 \%$ 2C\%202017.pdf (accessed November 2017).

39. Heineken (2014) Our Responsible Marketing Code. http://www.theheinekencompany.com/about-us/businessconduct/the-heineken-code-of-business-conduct (accessed February 2017).

40. Anheuser-Busch InBev (2014) Responsible Marketing and Communications Code. http://www.ab-inbev.com/con tent/dam/universaltemplate/abinbev/pdf/sr/rd/responsibledrinking/AB_InBev_2014_RMCC_English.pdf (accessed February 2017).
41. Beer Wine Spirits Producers' Commitments (2015) 2015 Progress Report: Beer, Wine and Spirits Producers' Commitments to Reduce Harmful Drinking. http://www. producerscommitments.org/wp-content/uploads/2016/07/ 2015-Progress-Report.pdf (accessed February 2017).

42. Noel JK, Babor TF \& Robaina K (2017) Industry selfregulation of alcohol marketing: a systematic review of content and exposure research. Addiction 112, Suppl. 1, $28-50$.

43. Jones SC, Thom JA, Davoren S et al. (2014) Internet filters and entry pages do not protect children from online alcohol marketing. J Public Health Policy 35, 75-90.

44. Madden M, Lenhart A, Cortesi S et al.2013) Teens, Social Media, and Privacy. http://www.pewinternet.org/ Reports/2013/Teens-Social-Media-And-Privacy.aspx (accessed February 2017).

45. Jernigan D, Noel J, Landon J et al. (2016) Alcohol marketing and youth alcohol consumption: a systematic review published since 2008. Addiction 112, Suppl. 1, 7-20.

46. Anderson P, de Bruijn A, Angus K et al. (2009) Impact of alcohol advertising and media exposure on adolescent alcohol use: a systematic review of longitudinal studies. Alcobol Alcohol 44, 229-243.

47. Health Canada (2013) Category Specific Guidance for Temporary Marketing Authorization: Caffeinated Energy Drinks. http://www.hc-sc.gc.ca/fn-an/alt_formats/ pdf/legislation/guide-ld/guidance-caf-drink-boiss-tma-amt-eng. pdf (accessed February 2017).

48. Harris J \& Munsell C (2015) Energy drinks and adolescents: what's the harm? Nutr Rev 74, 247-257.

49. Seifert SM, Schaechter JL, Hershorin ER et al. (2011) Health effects of energy drinks on children, adolescents, and young adults. Pediatrics 127, 511-528.

50. Senate of Canada (2016) An Act to Amend the Food and Drugs Act (Probibiting Food and Beverage Marketing Directed at Children). Ottawa: Senate of Canada; available at http://www.parl.ca/LegisInfo/BillDetails.aspx?billId=8439397 \&Language $=\mathrm{E}$

51. Health Canada (2016) Healthy Eating Strategy. http://www. canada.ca/content/dam/canada/health-canada/migration/ publications/eating-nutrition/healthy-eating-strategy-canadastrategie-saine-alimentation/alt/pub-eng.pdf (accessed February 2016).

52. Stop Marketing to Kids Coalition (2016) The Ottawa Principles. http://www.stopmarketingtokids.ca/wp-content/ uploads/2017/10/Stop-M2K-Ottawa-Principles.pdf (accessed February 2017).

53. Health Canada (2017) Toward Restricting Unhealthy Food and Beverage Marketing to Children: Discussion paper for public consultation. http://www.healthyeatingconsultations. ca/discussion-paper (accessed September 2017).

54. Montgomery KC \& Chester J (2009) Interactive food and beverage marketing: targeting adolescents in the digital age. I Adolesc Health 45, Suppl. 3, S18-S29.

55. World Health Organization (2016) Tackling Food Marketing to Children in a Digital World: Trans-Disciplinary Perspectives. Copenhagen: WHO Regional Office for Europe; available at http://www.euro.who.int/_data/assets/pdf_file/ 0017/322226/Tackling-food-marketing-children-digital-worldtrans-disciplinary-perspectives-en.pdf

56. Office of the Privacy Commission of Canada (2015) Results of the Global Privacy Enforcement Network Sweep. http://www.priv.gc.ca/en/opc-news/news-and-announcements/ 2015/bg_150902/ (accessed March 2017).

57. comScore (2015) Advertising Analytics: A Kellogg Case Study. How the Right Measurement Framework Can Increase Efficiency, Effectiveness \& RIO of Digital Advertising. Reston, VA: comScore Inc. 